\title{
POLITIKK
}

SKANDINAVISK TIDSSKRIFT

FOR INTERNASIONALE STUDIER

Årgang 77, Nummer 2, side 197-222, 2019, ISSN 1891-1757, www.tidsskriftet-ip.no, Publisert september 2019

\section{Fire nordiske Ruslands-relationer. På vej mod en fællesnordisk Ruslands-politik efter Krim og Trump?}

\author{
Hans Mouritzen ${ }^{1}$ \\ Dansk Institut for Internationale Studier (DIIS)
}

\begin{abstract}
Sammendrag
Rusland er en vigtig aktør for de nordiske lande ikke bare i Østersø-området, men også i Barents-regionen og i Arktis. For at opnå et fuldgyldigt billede af de involverede dynamikker bør de enkelte nordiske landes Ruslandsrelationer studeres samlet. De dansk-russiske, norsk-russiske, svensk-russiske og finsk-russiske relationer har udviklet sig ret forskelligt siden år 2000. Der eksisterer to barrierer for nordisk sikkerhedspolitisk samarbejde: (1) landenes forskellige geografiske beliggenhed og (2) bestemte indbyrdes idiosynkrasier, der ofte bunder i forskellige opfattelser af deres fælles historie. Derfor har det traditionelt været muligt for stormagter at praktisere 'del og hersk' i forhold til de nordiske lande, og det synes også at være lykkedes for Rusland siden år 2000. Men i kølvandet på Ukraine-konflikten og valget af Donald Trump til USA's præsident er der sket en konvergens mellem trusselsopfattelserne og dermed de geopolitiske interesser i de nordiske hovedstæder. I fravær af idiosynkrasier vil det nordiske sikkerheds- og forsvarspolitiske samarbejde derfor blive styrket, om end en fælles Ruslands-politik er urealistisk. Alle fire lande, ikke mindst Sverige, står over for vanskelige dilemmaer.
\end{abstract}

Nøgleord: bilaterale relationer • del og hersk • nordisk samarbejde $\cdot$ Rusland • småstater

I kølvandet på opstanden i Kiev og kuppet mod det pro-russiske styre i februar 2014 planlagde Sveriges udenrigsminister Carl Bildt en nordisk manifestation i byen. Tanken

${ }^{1}$ Dr.scient.pol., e-mail: hmo@diis.dk

^Korrespondanse: Hans Mouritzen, e-post: hmo@diis.dk

(C)2019 Hans Mouritzen. This is an Open Access article distributed under the terms of the Creative Commons Attribution 4.0 International License (http://creativecommons.org/licenses/by/4.0/), allowing third parties to copy and redistribute the material in any medium or format and to remix, transform, and build upon the material for any purpose, even commercially, provided the original work is properly cited and states its license.

Citation: Hans Mouritzen (2019). Fire nordiske Ruslands-relationer. På vej mod en fellesnordisk Ruslands-politik efter Krim og Trump?. Internasjonal Politikk, 77(2): 197-222. http://dx.doi.org/10.23865/intpol.v77.1319 
var, at de fem nordiske udenrigsministre skulle tage en spadseretur gennem det centrale Kiev for at vise deres deltagelse i sorgen over ofrene for Maidan-revolutionen et par uger forinden. Dernæst skulle de mødes med nytiltrådte ukrainske regeringsmedlemmer.

Som næsten-naboer til Ukraine og 'verdensmestre' i menneskerettigheder ville en sådan nordisk manifestation være en blåstempling af det nye styre. Imidlertid var det kun Martin Lidegaard, den danske udenrigsminister, der spadserede sammen med Bildt den 5. marts (Berlingske, 2014). Man behøver ikke være specielt kynisk for at fortolke episoden som et udtryk for forskellige grader af nordisk følsomhed i forhold til den russiske stormagt.

Forløbet viser ikke bare det høje ambitionsniveau for nordisk samarbejde inden for udenrigs- og sikkerhedspolitik, men også vanskelighederne ved at leve op til det i penible situationer. Ikke desto mindre har de nordiske regeringer alle beskrevet annekteringen af Krim som værende folkeretsstridig, og Norge og Island (begge uden for EU) har tilsluttet sig EU-sanktionerne mod Rusland. Den 10. april 2015 blev en kronik, signeret af de fem nordiske forsvarsministre, trykt i udvalgte nordiske aviser. ${ }^{2}$ Sikkerhedssituationen i landenes nærområder var angiveligt blevet forværret siden Ukraine-konflikten, så der var ikke længere tale om 'business as usual.' Det hed sig også, at 'russisk militær optræder udfordrende langs vores grænser' og at 'den russiske propaganda og politiske manøvrer søger at skabe splid mellem lande og i organisationer som EU og NATO'; de nordiske lande 'møder denne udvikling med solidaritet og styrket nordisk samarbejde', en solidaritet der også omfattede de baltiske lande.

\section{Den analytiske ambition}

Nordisk sikkerhedspolitisk samarbejde handler meget om Rusland i disse år, eftersom de nordisk lande ${ }^{3}$ opfatter denne stormagt som - mere eller mindre - truende. Vi skal derfor sammenligne hvert enkelt lands Ruslands-relation med henblik på, om de er indbyrdes relaterede og åbner mulighed for nordisk samarbejde. Hvordan påvirker USA, den vigtigste sikkerhedspolitiske magt uden for regionen, dette billede?

Nordisk udenrigs- og sikkerhedspolitisk samarbejde, som det foregår ved bl.a. de regelmæssige udenrigs- eller forsvarsministermøder, lever ikke i sin egen 'nordistiske' boble (f.eks. Iso-Markku m.fl., 2018); det kan kun forstås som den laveste fællesnævner mellem de geopolitiske dagsordener og politiske idiosynkrasier, der hersker i hvert enkelt af de nordiske hovedstæder. På den anden side er det ikke nok kun at fokusere på ét nordisk land ad gangen og hvordan det positionerer sig i

\footnotetext{
${ }^{2}$ Oprindelig et svensk initiativ. Se Wammen et al. (2015).

${ }^{3}$ Island indgår ikke i nærværende analyse, eftersom landets sikkerhedspolitiske situation af indlysende geografiske grunde afviger markant fra de fire øvrige landes.
} 
stormagtsspillet. En sådan analyse ville blot reflektere et nationalt (småstats)snæversyn blandt såvel udøvere som eksperter og medier i hver enkelt hovedstad. For at opnå et fuldgyldigt billede af de involverede dynamikker må vi være opmærksomme på de tilsigtede og utilsigtede interaktionseffekter mellem de nordiske Ruslands-politikker. Nogle af dem kan faktisk være initieret udenfor regionen, selvom dette sjældent er synligt for det blotte øje. Denne analytiske ambition gør det nødvendigt at studere alle fire nordiske Ruslands-relationer inden for en falles ramme. I denne må også fluktuationer i den amerikanske stormagtspolitik i regionen inddrages. Og eftersom de nordiske lande ikke kun interagerer med Rusland i Østersøregionen, men også i Barentsregionen og i Arktis omkring Polarhavet, må flere arenaer inddrages.

Modsat f.eks. langsigtet militær oprustning handler dagligdags geopolitik i høj grad om to forbundne ting: (1) at udnytte (eller endog skabe) splittelser mellem stater i en modstående (formel eller uformel) alliance (Crawford, 2011); og (2) forebygge eller tilsløre tilsvarende modsætninger i ens egen lejr. Det sidstnævnte gøres via offentlige erklæringer om sammenhold, ubrydelig solidaritet o.l., om muligt kombineret med faktisk adfærd, der kan underbygge erklæringernes troværdighed. Denne legen 'del og hersk'4 kan genfindes på alle niveauer af politik, for eksempel når en regering forsøger at udnytte eller endog skabe splittelser i den parlamentariske opposition. Så der er ikke noget odiøst ved, at EU forsøger at udnytte splid mellem Belarus og Rusland, eller hvis sidstnævnte skulle finde og udnytte sprækker mellem de nordiske lande. Alligevel ser vi et forsøg på udskamning af Rusland i ovennævnte nordiske fælleskronik: 'den russiske propaganda og politiske manøvrer søger at skabe splid mellem lande'.

Af ovennævnte analytiske ambition følger naturligt nok, at sprækker i den nordiske facade må tillægges større vægt end harmoni. Den brede ambition, der omfatter fire nordiske lande, betyder også, at vi må male med en større pensel end i studier af et enkelt land; detaljer, der kan være vigtige i forhold til andre perspektiver, må negligeres her. Først analyseres barriererne for nordisk sikkerhedspolitisk samarbejde, som de har vist sig i historiske nøglesituationer. Så følger undersøgelser af langtidstrends for hver af de fire russisk-nordiske relationer siden ca. 2000 (indtil Krimkrisen 2014) og en sammenligning af dem. Dernæst retter vi blikket mod det øgede nordiske sikkerheds- og forsvarspolitiske samarbejde efter Georgien-krigen, hvorefter vi vender tilbage til de nationale Ruslands-relationer efter 2014. Det følgende afsnit stiller spørgsmålet, hvordan 'Trump-faktoren' efter 2016 har påvirket dette i forvejen komplicerede billede. Der vil blive argumenteret for, at alle involverede lande, og i særlig grad Sverige, står over for vanskelige dilemmaer. Som tidligere tilbyder de nordiske lande Rusland rigelige muligheder for at praktisere 'del og hersk'. Ikke desto mindre vil der blive argumenteret for, at udsigterne for nordisk sikkerheds- og

\footnotetext{
${ }^{4}$ Se f.eks. Daniel Nexon (2009); Eric Posner et al. (2009); eller Mikael Wigell \& Antto Vihma (2016).
} 
forsvarspolitisk samarbejde i dag er bedre end nogensinde, om end en fellesnordisk Ruslands-politik er urealistisk.

\section{Geopolitiske og idiosynkratiske barrierer for nordisk samarbejde}

Forbandelsen, der historisk har hvilet over nordisk sikkerheds- og forsvarspolitisk samarbejde, går ud på, at entusiasmen for det nordiske aldrig har omfattet alle landene samtidig. Typisk har ét eller højst to lande været ivrige, mens resten har været mere eller mindre reserverede. Med andre ord har nordisk samarbejde aldrig været vitalt for alle på én og samme gang. Den dybereliggende årsag til dette er geopolitisk: den tyndt befolkede nordiske region har historisk grænset op til den ene eller anden militære stormagt. Disse har imidlertid af geografiske grunde påvirket og truet de enkelte hovedstæder i vidt forskelligt omfang, hvilket har umuliggjort en samlet nordisk front. I tillæg har nogle mindre rationelle barrierer ofte spillet ind.

I slutningen af 1930'erne var det vitalt for det neutrale Danmark at fremhæve en fælles nordisk identitet over for dets stærke nabo mod syd; ${ }^{5}$ det var også vigtigt for Finland i forhold til dets store nabo mod øst. Imidlertid blev den danske diskurs om at 'Danmarks sydgrænse er også Nordens sydgrænse' tilbagevist af Oslo. Bitterhed over tabet af Østgrønland til Danmark i 1933, som fastslået af den Internationale Domstol i Haag, betød, at Norge var uvilligt til at støtte Danmark diplomatisk i en eventuel konflikt med Tyskland om grænsen i Sønderjylland.

Forhandlingerne om et Nordisk Forsvarsforbund 1948-49, der involverede Sverige, Norge og Danmark, blev ført på grundlag af en nogenlunde ensartet opfattelse af en sovjetisk trussel. Udsigterne til en aftale var derfor gode. Forhandlingerne slog imidlertid fejl på grund af svensk-norsk uenighed; Sverige ønskede et neutralt forbund, mens Norge ønskede et vestligt orienteret forbund, som dog under alle omstændigheder var sekundært i forhold til nye planer om en såkaldt 'Atlantpagt', det senere NATO. Forklaringer på uenigheden har betonet, at de norske politikere var i eksil i London under krigen, norsk bitterhed over Sveriges påståede 'svigt' af Norge under den tyske besættelse og endelig paralleller mellem det planlagte forsvarsforbund og den upopulære union med Sverige før 1905 (Leraand, 2014).

Trods landenes forskellige sikkerhedspolitiske aksiomer (Danmark og Norge NATO-medlemmer, Sverige neutralt og Finland 'neutralitetsstræbende') blev der holdt såvel nordiske udenrigs- og forsvarsministermøder under den Kolde Krig. ${ }^{6}$ Den nordiske identitet var vigtig for Finland i dets forhold til Sovjetunionen (den aftog, så snart Sovjetunionen var kollapset). For Danmark blev den nordiske identitet vigtig

\footnotetext{
${ }^{5}$ Således karakteriserede statsminister Thorvald Stauning Danmark som en 'gammel nordisk [HM fremh.] nation, som ærligt har fulgt en upartisk neutralitetspolitik i forventningen om at kunne bevare sit fredelige nationale liv' (tale om aftenen 9. april 1940, se Historieportalen 2019).

${ }^{6}$ De nordiske institutioner, der blev etableret under den Kolde Krig - Nordisk Råd og Nordisk Ministerråd - behandlede ikke sikkerheds- og forsvarspolitik, netop på grund af de forskellige aksiomer på disse områder i hovedstæderne.
} 
på mindre eksistentielle måder: da Danmark var blevet det eneste nordiske land i EF fra 1973, kunne landet promovere sig selv som 'brobygger' mellem Norden og EF. I NATO kunne forestillingen om at opretholde en 'nordisk balance' (Brundtland, 1966) udnyttes af både Norge og Danmark til at undgå amerikanske baser eller atomvåben på deres territorier: det var essentielt, lød argumentet, at opretholde Norden som et lavspændingsområde, ikke mindst for at undgå at Finland kom under yderligere pres fra Sovjetunionen. Disse selvpålagte begrænsninger i alliancepolitikken var også for både Danmark og Norge et instrument i det bilaterale forhold til Sovjetunionen.

Med bortfaldet af koldkrigskonstellationen var der gode udsigter for nordisk udenrigs- og sikkerhedspolitisk samarbejde. Og med sin position uden for EF og senere EU havde Norge en interesse $i$ at fremme nordisk udenrigspolitisk samarbejde. Men med deres EU-medlemskaber fra 1995 gjorde Sverige og Finland alt for at vise sig som 'gode europæere', hvilket indebar en lav profil i forhold til det specifikt nordiske samarbejde.

Handlefriheden for hvert af de fire lande var forøget dramatisk, hvilket imidlertid ikke var nogen fordel for det indbyrdes samarbejde. Nordiske sikkerheds- og forsvarspolitiske dilemmaer handlede ikke længere om solidaritet med det ene eller andet nordiske land, men derimod om deltagelse i FN- eller USA-ledede interventioner ude i verden. Danmarks 'superatlantisme' (Mouritzen, 2006) efter 2001 - især Irak-interventionen i marts 2003 uden klart FN-mandat - var vanskelig at forstå for de andre nordiske lande, selv for Danmarks norske NATO-allierede.

\section{Samarbejdsbarrierer i Nordens 'nære udland'}

Med nedsmeltningen af den sovjetiske magtpol og polarisens bogstavelige smeltning åbenbarede sig to nye geografiske områder for nordisk samarbejde: Arktis og den sydlige Østersøs østbred. De nordiske lande interagerer med Rusland på begge disse arenaer, direkte eller indirekte.

Samarbejde og jalousier på den baltiske arena

Politik over for Estland, Letland eller Litauen er også indirekte Ruslands-politik: jo mere sikkerheds- og forsvarspolitisk samarbejde med disse lande desto mere vil det forringe forholdet til Rusland. Danmarks i sidste ende succesfulde bestræbelser for at sikre de baltiske lande medlemskab af NATO førte mildest talt til løftede øjenbryn i Moskva. Opmuntret af Washington har Danmark senere hen arbejdet på at udvide det nordiske sikkerheds- og forsvarspolitiske samarbejde til også at omfatte de baltiske lande. Siden ca. 2008 er denne bestræbelse blevet helhjertet støttet af Stockholm, mens Oslo og Helsingfors er forblevet reserverede ${ }^{7}$ (de baltiske lande er her blevet anset for at være for eksponerede og for anti-russiske).

\footnotetext{
${ }^{7}$ Det diplomatiske udtryk for dette er, at N5, samarbejdet mellem de fem nordiske lande, har en 'værdi i sig selv' (diplomatinterview, Helsingfors 24. august 2017). Ifølge den svenske ensidige
} 
Mindre bekymrende for Moskva har det nordiske samarbejde også handlet om at sikre de baltiske lande EU-medlemskaber og at bistå dem samfundsmæssigt. Men jo mere sammenlignelige nabostater på denne måde samarbejder hen mod fælles mål ('parallel action'), desto mere konkurrerer de også. ${ }^{8}$ De nordiske lande har ikke været undtaget fra den regel. Hvilket nordisk land har f.eks. gjort mest for de baltiske lande? Hvilken nordisk hovedstad skulle være vært for det nyoprettede Østersøråd? Hvilket nordisk land skulle indtage lederrollen i den nye 'spændende' Østersøregion? Danmark og Sverige var involverede i en venskabelig konkurrence om den titel i 1990'erne. Danmarks fortrin var dets NATO-medlemskab, mens Sveriges styrke var dets historiske bånd med balterne, inklusive dets baltiske diaspora. Da interessen for regionen dalede i det nye årtusind, aftog også den dansk-svenske 'parallel action'.

Samarbejde og konkurrence i Arktis?

Arktisk politik er også i nogen grad Ruslands-politik. Men der har ikke været den samme nordiske 'parallel action' i forbindelse med den arktiske hype (fra omkring 2007), som der tidligere var i Østersøregionen. Forklaringen er, paradoksalt nok, at de nordiske landes arktiske dagsordener har været noget forskellige. I stedet for at træde på hinandens tæer har der været substantielle nuancer: Norge og det danske rigsfællesskab (Danmark, Grønland og Færøerne) har primært betonet levevilkårene for beboerne i Arktis, mens Sverige og Finland i højere grad har betonet globale temaer som arktisk dyreliv og miljø. Der er ingen nordiske formøder i Arktisk Råd (som udover de nordiske lande omfatter Rusland, Canada og USA). Samarbejds- og konfliktlinjer inden for denne organisation går på kryds og tværs af hinanden. Danmark har gentagne gange understreget Ruslands konstruktive bidrag til det arktiske samarbejde.

I maj 2008 var rigsfællesskabet vært for en udenrigsministerkonference i Ilulissat (Grønland), hvor et nyt arktisk forum blev skabt, Arctic-5, bestående af kyststaterne ved Polarhavet: Rusland, Norge, rigsfællesskabet (i kraft af Grønland), Canada og USA (Rahbek-Clemmensen \& Thomasen, 2018). Formålet var at signalere til verdenssamfundet, at disse fem lande ville dele Polarhavssokkelen mellem sig, og at dette kunne gøres på fredelig og ansvarlig måde ved at følge UNCLOS (The United Nations Convention on the Law of the Sea). Dette initiativ fra rigsfællesskabets side skabte megen undren i de andre nordiske hovedstæder, fordi det blev taget uden for Arktisk Råds regi. Men det blev værdsat ikke mindst af Rusland. Der var faktisk en snert af 'parallel action' nogle få måneder mellem rigsfællesskabet og Norge, eftersom Norge nærede de same Ilulissat-agtige ambitioner som Danmark.

Solidaritetserklæring fra 2009 vil Sverige ikke 'forblive passiv' i tilfælde af katastrofe eller militært angreb på et EU-medlemsland eller et nordisk land. Og Sverige forventer det samme fra dem. Se Kempf (2012). Erklæringen rettede sig ikke mindst til de baltiske lande.

${ }^{8}$ Om begrebet 'parallel action', se Mouritzen (1997), s. 37-42. 
Men København var hurtigere til at sende invitationer ud, hvilket skabte en del norsk irritation. ${ }^{9}$

En territoriel 'kamp om Nordpolen' kan forudses mellem Rusland og rigsfællesskabet (muligvis også Canada). Hvis to lande ifølge geologisk ekspertise begge har legitime krav på et område (som det er sandsynligt i dette tilfælde), kan den territorielle opdeling kun foretages gennem bilaterale forhandlinger. For Danmark er det derfor essentielt at sørge for fornuftige relationer med Rusland som grundlag for sådanne forhandlinger. Rusland forsøgte faktisk at få bilaterale forhandlinger i stand allerede fra 2016, men det blev afvist af Danmark.

Barents-samarbejdet, som kort skal berøres nedenfor, er i vid udstrækning et norsk-russisk anliggende, skønt de andre nordiske lande er medlemmer - nogle mere aktive end andre - af 'Barents Euro-Arctic Council' grundlagt i 1992. Man kan næppe tale om nordiske jalousier her, eftersom Norge anerkendes som Nordens i særklasse nr. 1 i denne sammenhæng (bl.a. i kraft af sit økonomiske bidrag og sekretariatet i Kirkenes, Norge).

\section{Bilaterale relationer med Rusland: trendanalyser}

Da vi nu har set barriererne for nordisk samarbejde, går vi over til trendanalyser for hver enkelt af de fire Ruslands-relationer. Traditionelt har de enkelte nordiske landes Ruslands-politikker været forskellige og ukoordinerede. Det er, hvad der kan forventes af suveræne lande uden indbyrdes allianceforpligtelse, trods folkelige forventninger om indbyrdes solidaritet. I analysen nedenfor vil de nordiske lande blive opdelt i to par, Danmark og Sverige versus Norge og Finland.

De dansk-russiske og svensk-russiske relationer: fluktuerende og ude af takt

Danmarks og Sveriges Ruslands-relationer har begge fluktueret betydeligt siden årtusindskiftet. De har til tider været pragmatiske, endog hjertelige, men på andre tidspunkter været præget af isnende kulde. Men ikke på samme tid: når de danskrussiske relationer har været dybfrosne, har de svensk-russiske været gode. Og omvendt: når Sverige er havnet i den russiske dybfryser, er de dansk-russiske relationer blevet betragteligt forbedret (Mellander \& Mouritzen, 2016).

I efteråret 2002, da der generelt var gode relationer mellem Rusland og Vesten, planlagdes det første russiske statsbesøg i Danmark siden 1964. Det blev imidlertid aflyst, da den alvorligste krise i de bilaterale relationer siden den Kolde Krig udviklede sig. Den tidligere tjetjenske vice-premierminister og general Akhmed Zakajev, som var beskyldt af Moskva for at stå bag terrorangrebet på et teater i Moskva (23. oktober), holdt tale ved den tjetjenske Verdenskongres i København kort derefter. Han blev anholdt og kortvarigt tilbageholdt af dansk politi, men blev ikke udleveret til Rusland som krævet af Moskva.

\footnotetext{
${ }^{9}$ Interview med den daværende danske udenrigsminister Per Stig Møller (12. november 2015).
} 
Den danske statsminister Anders Fogh Rasmussen benyttede lejligheden til at understrege ytringsfriheden i Danmark og kvaliteterne ved den danske retsstat (i modsætning til den russiske, forstås). Endvidere betonede han i en aviskommentar (Fogh Rasmussen, 2002) vigtigheden af at trodse stormagtspres, som han selv netop havde gjort, i modsætning til Danmarks traditionelle 'småstatsadfærd', som ifølge Fogh Rasmussen i perioder havde bestået i en unødig tilpasning til Nazi-Tyskland eller Sovjetunionen ('fodnotepolitikken' under den Kolde Krig). ${ }^{10}$

Udover at aflyse statsbesøget medførte Fogh Rasmussens værdidomme og historiske sammenligninger, at Danmark havnede i den russiske dybfryser i adskillige år. Der var nu heller ikke nogen danske forsøg på at formilde russerne, tværtimod. I forbindelse med 60-års jubilæet for afslutningen af 2. verdenskrig i Europa (2005) bad Fogh Rasmussen Rusland om at undskylde for den sovjetiske okkupation af de baltiske lande fra 1944 til 1991. Desuden støttede Danmark, om end forgæves, at Ukraine og Georgien skulle tildeles 'Membership Action Plans' ved NATO-topmødet i Bukarest i april 2008, trods kraftig russisk modstand.

I samme periode førte Sverige derimod en ret så forsigtig Ruslands-politik. For eksempel holdt Stockholm lav profil i forbindelse med den 'Orange revolution' i Ukraine 2004-05. I modsætning til i Danmark kritiseredes valghandlingen ikke direkte, da Yanukovich - Moskvas foretrukne kandidat - blev valgt til præsident.

Men da Rusland intervenerede i Georgien, som svar på det georgiske bombardement af den sydossetiske hovedstad Tskhinvali i august 2008, var reaktionen fra Carl Bildt, udenrigsminister siden 2006, blandt de skarpeste i Europa. Han sammenlignede Ruslands intervention og dens legitimering med Nazi-Tysklands underminering af Tjekkoslovakiet i 1938-39: beskyttelsen af en minoritet i et mindre naboland, det være sig sudetertyskere eller ossetere med russiske pas. Rusland, som af indlysende grunde er sensitivt i forhold til enhver sammenligning med NaziTyskland, puttede nu Sverige og navnlig Carl Bildt i dybfryseren.

Lige så lidt som i det danske tilfælde var der svenske forsøg på at undskylde ordvalget eller at formilde Moskva på andre områder i årene fremover. Tværtimod tog Sverige sammen med Polen føringen i EU's østlige naboskabsprogram, som Rusland i stigende grad opfattede som fjendtligt. Desuden fremførtes skarp kritik af det russiske parlamentsvalg i 2011, Duma-loven i 2013 mod LGBTQ-'propaganda' og dommen mod den russiske oppositionspolitiker Aleksej Navalny.

Det svenske forsvar var blevet markant beskåret siden årtusindskiftet, og hovedopgaven blev i 2004 officielt ændret fra territorialforsvar til krisestyring i internationale konflikter, bl.a. med den begrundelse, at 'Rusland var ved at tilnærme sig vestlige værdier'. ${ }^{11}$ Men på baggrund af det spændte bilaterale forhold, herunder russisk militærs øvelsesaktivitet i nærområdet, blev Rusland nu officielt betegnet som

\footnotetext{
${ }^{10}$ Udtrykket refererer til de fodnoter i NATO-kommunikéer i 1980'erne, hvor Danmark reserverede sig i forhold til opstillingen af amerikanske mellemdistanceraketter i Europa.

${ }^{11}$ Ifølge den svenske forsvarschef, citeret i Pyykönen (2016, s. 78).
} 
en sikkerhedspolitisk trussel. I denne atmosfære var det mildest talt foruroligende for den svenske offentlighed at erfare fra forsvarschefen (december 2012), at Sverige kun ville kunne modstå et angreb fra en 'fremmed magt' $i$ ca. en uge. ${ }^{12}$

Edward Snowden-afsløringen samme år af at svensk efterretningstjeneste bistod USA i udspionering af Rusland, gjorde næppe det bilaterale forhold til Rusland bedre. Langfredag året efter øvede russiske kernevåbenudstyrede bombefly angiveligt et angreb på FRA, 'Försvarets Radioanstalt' ved Stockholm. På grund af påskeferien var der ikke tilstrækkeligt afvisningsberedskab i det svenske flyvevåben.

Medens det svensk-russiske forhold således forringedes markant fra 2008, forbedredes det dansk-russiske forhold. Det er sandsynligt, at Danmark med den stigende interesse omkring Arktis følte et behov for at forbedre forholdet til netop Rusland, den arktiske stormagt. I 2009 var danske myndigheder hurtige til at tillade, at Nord Streams naturgasledning mellem Rusland og Tyskland kunne passere gennem dansk territorialfarvand i Østersøen (medens Sverige var længere om at give miljøgodkendelse for passage gennem sin økonomiske zone), og Putin udtrykte sin taknemmelighed til den ny danske statsminister Lars Løkke Rasmussen. I de følgende år bevarede Danmark sin nyvundne goodwill i Moskva ved at være påfaldende forsigtig i officielle kommentarer til det russiske Duma-valg i 2011 og til den nævnte LGBTQ-lov i 2013, ligesom dommen mod Navalny blev ignoreret. Officielle statsbesøg med royal deltagelse fandt sted i København 2010 og Moskva 2011. Det var ikke før Ukraine-konflikten i 2014, at de to landes Ruslands-politikker begyndte at konvergere, skønt Sverige stadig var mest Ruslands-kritisk. Som nævnt var det Carl Bildt, der tog initiativ til manifestationen i Kiev.

De finske og norske Ruslands-relationer: kontinuitet og pragmatisme

Ruslands relationer med Finland og Norge har ikke fluktueret så meget som relationerne med Danmark og Sverige. Kontinuitet og pragmatisme har været kendetegnende, om end betinget af forskellige parametre for hvert af de to lande.

Finlands store nabo mod øst har været aksiomatisk for udenrigspolitikken lige siden landets selvstændighed. Dets historiske erfaring tilsiger ikke at stole på udenlandsk militær bistand; under Vinterkrigen kom ingen, når der bortses fra frivillige og materiel bistand fra især Sverige. Finland har lært at klare sig selv, både politisk (det 'gode naboforhold' til Sovjetunionen under den Kolde Krig) og endog militært (Vinterkrigen). På denne baggrund kastede Finland sig ikke i armene på NATO, da muligheden for medlemskab åbnede sig midt i 1990'erne. Den kan spilles som et kort i Ruslands-politikken, men medlemskab er 'for tiden ikke på dagsordenen', som det hedder i officielle udtalelser. Samarbejde med NATO gennem

\footnotetext{
${ }^{12}$ Denne udtalelse signalerer også, at Sverige kalkulerer med at modtage ekstern assistance. Dette fremgik allerede af den unilaterale Solidaritetserklæring (2009).
} 
partnerskabsprogrammet har været vigtigt, men mindre synligt end i Sveriges tilfælde, ${ }^{13}$ da Finland generelt foretrækker at beholde sine styrker hjemme. Betinget af dets beliggenhed og historiske erfaring bibeholdt Finland territorialforsvaret og værnepligten, da andre gik over til udrykningsforsvar baseret på professionelt mandskab (Saxi, 2011, s. 54-5). I modsætning til Sverige kalkulerer Finland i dag ikke med udenlandsk bistand i krigstilfælde (Pyykönen, 2016, s. 84).

Interventionen i Georgien eller russiske øvelser i Finlands nærområde har derfor ikke givet anledning til abrupte brud i landets forsvarspolitik. Kontinuitet har også præget udenrigspolitikken, skønt daværende udenrigsminister Alexander Stubb formulerede sig uhyre kritisk, efter finsk målestok, om interventionen. Pragmatismen står som altid stærkt, skønt den Kolde Krigs 'finlandisering' - det særlige forhold østover med virkninger på indenrigspolitikken - ikke er på tapetet. I fravær af NATO-medlemskab har Finland været stærk tilhænger af EU-integration med euroen som valuta og ivrig deltager i det europæiske sikkerheds- og forsvarspolitiske samarbejde. Med ansvaret for EUs 'Nordlige Dimension' (Gebhard, 2013), i praksis samarbejdet med det nordvestlige Rusland, præsenterede Finland sig som brobygger mellem EU og Rusland. Dette nåede sit højdepunkt i sen-halvfemserne og de første år efter årtusindskiftet, da 'Einbindung' af Rusland stadig blev anset for realistisk.

Rusland er også aksiomatisk i norsk udenrigspolitik. Medlemskabet af NATO udgør den grundlæggende afskrækkelse. Det andet ben i Norges Ruslands-politik er imidlertid nordområdepolitikken, herunder grænsesamarbejdet (Barents-samarbejdet). Dette finder sted bilateralt og gennem 'Barents Euro-Arctic Council', etableret på initiativ af Norge og Rusland lige efter den Kolde Krig. F.eks. kan nordmænd og russere bosiddende mindre end 30 kilometer fra grænsen krydse den visumfrit. Som med finsk grænsesamarbejde handler det både om konkret indbinding og bredere udenrigspolitik. Specifikt har det også været essentielt for Norge at forhindre mareridtet, at sovjetisk nukleart affald fra Kola-halvøen skulle forurene nogle af verdens rigeste fiskeområder i Barentshavet og Norskehavet. Derfor har miljøaspektet høj prioritet i Barents-samarbejdet.

Før Ukraine-konflikten var de norsk-russiske relationer stabile og til tider endog særdeles gode. Da Danmark støttede NATOs 'Membership Action Plans' og på længere sigt medlemskab for Ukraine og Georgien ved topmødet i Bukarest i april 2008, var Norge imod. ${ }^{14}$ Norge var også forsigtig i sine kommentarer til Ruslands intervention i Georgien nogle måneder senere. Dette lå i linje med Norges generelle Ruslands-politik, men mere specifikt kan det også have været et forsøg på at gøde jorden for en norsk-russisk grænseaftale i Barentshavet. ${ }^{15}$ Efter en 40 års 'frossen konflikt' om grænsedragningen lykkedes det at lande en aftale i 2010.

\footnotetext{
${ }^{13}$ For eksempel deltog Finland modsat Sverige ikke med fly i Libyen-interventionen i 2011. Se Pyykönen (2016), s. 76, 121.

${ }^{14}$ Se Mouritzen \& Wivel (2012): 118-9, 126-27.

${ }^{15}$ Maria Mellanders interview med Per Stig Møller, daværende dansk udenrigsminister, den 10. december 2013.
} 


\section{Efter Georgien: en ny start for nordisk forsvarssamarbejde}

Fra 2008 oplevede nordisk sikkerheds- og forsvarspolitisk samarbejde et boost. Den vigtigste drivkraft var finansiel: stagnerende eller skrumpende budgetter efter finanskrisen kombineret med stigende priser på forsvarsmateriel (Saxi, 2011, s. 15-23). Arbejdet med Stoltenberg-rapporten fra $2009,{ }^{16}$ som skabte rammerne for den nye satsning, blev igangsat af de nordiske udenrigsministre for Georgien-krigen. Da rapporten blev offentliggjort i februar 2009, blev den imidlertid til 'high politics' med sin ambition om en nordisk udenrigs- og sikkerhedspolitisk union (s. 18). Og debatten om rapporten fik næring af interventionen i Georgien, som næsten skyggede for den oprindelige målsætning om besparelser gennem fælles materielindkøb.

NORDEFCO (Nordic Defence Cooperation), et af rapportens vigtigste resultater, byggede videre på allerede eksisterende elementer af forsvarssamarbejde $\mathrm{i}$ Nordskandinavien mellem Norge, Sverige og Finland. Island og Danmark har også tilsluttet sig, sidstnævnte i starten med en vis tøven, idet man frygtede at NORDEFCO i bedste fald ville være spild af tid, i værste fald blive en konkurrent til NATO (Bailes, 2016).

NORDEFCOs geografiske område omfatter dele af Arktis i form af Nordskandinavien ('Scandinavian Arctic') og Island. I førstnævnte område forekommer regelmæssige grænseoverskridende flyøvelser (CBT, 'cross-border training'). I 2014 var Island vært for det såkaldte 'Iceland Air Meet' (Dahl, 2014) med overvågning af islandsk luftrum af nordiske kampfly, en prestigefyldt begivenhed med alle de nordiske udenrigs- og forsvarsministre til stede. ${ }^{17}$

NORDEFCO kunne give mening for Norge, da NATO havde vist beskeden interesse i nordområderne, Norges vigtigste sikkerhedspolitiske prioritet. NORDEFCO kunne her være et nyttigt supplement og i øvrigt være mindre provokerende $i$ russiske øine end NATO-styrker. Imidlertid var og er NORDEFCO endnu vigtigere for svensk og finsk sikkerhedspolitik. Mens NATO-medlemskab er sensitivt for begge disse lande indenrigspolitisk og i forhold til Rusland (mildest talt), er NORDEFCO acceptabelt i begge henseender på linje med svensk-finsk forsvarssamarbejde. Som nævnt var Danmark indledningsvis mindre entusiastisk (Saxi, 2011, s. 55-59). Imidlertid har en positiv amerikansk vurdering af NORDEFCO, som et middel til at forberede Sverige og Finland til NATO-medlemskab, påvirket den danske holdning.

Men midt i denne positive udvikling kan bilaterale idiosynkrasier slå ned som et lyn fra en klar himmel. Bortset fra at Norge ikke købte svenske Jas Gripen kampfly og endog kritiserede dem offentligt, trak Norge - efter svensk opfattelse - sig alt for

\footnotetext{
${ }^{16}$ Se Stoltenberg (2009). For at markere 10-års jubilæet for rapporten publicerede de fem nordiske udenrigspolitiske institutter i maj 2019 en evaluering af den aktuelle status for nordisk udenrigsog forsvarspolitisk samarbejde. Se Ten Years On (2019). Se også NUPI (2018).

${ }^{17}$ Ikke at forveksle med den roterende NATO-overvågning over Island siden lukningen af Keflavik flybasen.
} 
sent ud af det fælles svensk-norske 'Archer artillery' projekt (de Briganti, 2013). En ophedet uenighed fik landene til at trække sine forsvarsattachéer tilbage fra hhv. Oslo og Stockholm i 2013, og de vendte ikke tilbage før 2017.

I det store billede har der imidlertid fundet en markant styrkelse sted af nordisk sikkerheds- og forsvarspolitisk samarbejde efter Stoltenberg-initiativet. ${ }^{18}$ Men hvad skete i kølvandet på Ukraine-konflikten? Lad os først se på, hvordan de enkelte landes Ruslands-politik blev påvirket.

\section{Efter Krim: ildevarslende spekulationer om Gotland}

I betragtning af Carl Bildts upopularitet i Moskva forventedes det alment, at de svensk-russiske relationer ville forbedres med hans tilbagetræden efter det borgerlige valgnederlag i september 2014. Dette skete imidlertid ikke. For det første var Ukraine-konflikten stadig uløst. For det andet forekom angiveligt fremmed mini-ubådsaktivitet i den stockholmske skærgård, netop mens den nye regering var ved at flytte ind i regeringskontorerne. Da den, med rette eller urette, blev opfattet som russisk, var der ingen stemning i Stockholm for at 'starte forfra' i forhold til Rusland. Den nye udenrigsminister Margot Wallström var ikke mere forsigtig end sin forgænger; i forlængelse af mordet på oppositionspolitikeren Boris Nemtsov i februar 2015 talte Wallström om 'Putins terrorstyre'. ${ }^{19}$

Et krigsscenarie, der involverede Gotland, kom i omløb: eftersom de baltiske lande, med rette eller urette, ansås for truet af Rusland, fik Gotland midt i Østersøen en vital strategisk betydning. Hvis Rusland fik militær kontrol med Gotland, ville det være i stand til, ifølge denne tankegang, at forhindre NATO-styrker i at komme sine baltiske allierede til undsætning. Dette fokus på Gotland var naturligvis ekstremt ubehageligt for Sverige. Paradoksalt nok var den strategiske buffer, som Sverige havde opnået gennem de baltiske landes uafhængighed, nu blevet til en belastning. Sammen med næsten-krænkelser af svensk luftrum og påstået russiske cyberangreb (såkaldte 'aktive tiltag', Kragh \& Åsberg, 2017) skabte dette noget nær krigspsykose i Sverige. Uforklarlige hændelser som sabotage mod radio- og TV-tårne blev tilskrevet russiske agenter i medierne (Svenska Dagbladet, 2016). Hvis Ruslands sigte var at sætte en skræk i livet på svenskerne, var det ifølge Wallström lykkedes til fulde: 'Här är svenskar, för första gången, på allvar rädda. Rädda för Ryssland, för vad de skall ta sig till, och tycker att de är oförutsägbara ... och gör saker som är folkrättsvidriga' (Svenska Dagbladet, 2014).

Udover en generel, men i sagens natur langsommelig, tilbagevenden til territorialforsvar (og værnepligt), har Sverige svaret med at genbefæste Gotland.

\footnotetext{
${ }^{18}$ Stoltenberg-initiativet omfattede ikke de baltiske lande. For at imødekomme baltisk utilfredshed med dette udarbejdedes en dansk-lettisk vismandsrapport i 2010 om nordisk-baltisk udenrigs- og sikkerhedspolitisk samarbejde. Se NB8 (2010). I efteråret 2014, dvs. efter Krim, blev udvalgte NORDEFCO-projekter åbnet for baltisk deltagelse.

${ }^{19}$ Mordet 'förstärker bilden av Putins skräckvälde'. Se Dagens Nyheter (2015).
} 
Cyberforsvaret er blevet styrket. Forsvarsbevillingerne er øget, og borgerlige oppositionspartier konkurrerer om at forlange de største merbevillinger. NORDEFCO er blevet styrket, og især det bilaterale svensk-finske samarbejde er intensiveret. Ved Wales-topmødet i 2014 blev et 'Enhanced Opportunities Programme' vedtaget, som indebærer, at Sverige og Finland er NATOs tætteste partnere. ${ }^{20}$ Der blev også underskrevet 'Host Nation Support' memoranda med de to lande, der tillader fælles militærøvelser på deres territorier og bistand fra NATO-styrker efter invitation. I maj 2015 foregik 'Arctic challenge exercise', den største flyøvelse i verden det år, i Nordsverige (Sveriges store tyndt befolkede områder her er de bedste $\mathrm{i}$ Europa til formålet). I juni samme år fandt den store 'Baltops' landgangsøvelse sted på Sveriges sydkyst med deltagelse af styrker fra flere NATO-lande, herunder USA. I september 2017 foregik de to største militærøvelser i regionen efter den Kolde Krig: Ruslands/Belarus'Zapad og SverigesAurora med deltagelse af adskilligeNATO-landes styrker (OSW, 2017).

Alligevel er NATO-medlemskab ikke på dagsordenen for den socialdemokratisk ledede regering $i$ indeværende mandatperiode (der strækker sig til 2022). Alle borgerlige partier har tilsluttet sig Liberalernas længe nærede ønske om medlemskab. Dette betyder imidlertid ikke, at en ansøgning om medlemskab bliver afsendt, selv om der skulle ske et regeringsskifte efter næste valg. Den uskrevne regel er, at ændring af landets alliance-status kun kan ske med konsensus mellem de to 'ansvarlige' partier, Socialdemokraterna og Moderaterna ${ }^{21} \mathrm{I}$ denne situation har forsvarsminister Peter Hultqvist betonet i en aviskommentar, at det bilaterale forsvarssamarbejde med USA bør styrkes, ikke mindst vedrørende interoperabilitet, fælles øvelser og internationale operationer (Sveriges regering, 2015).

En særlig vanskelighed for Sverige i forhold til Rusland er manglen på 'neutrale' konversationsemner som Norges og Finlands grænseregionssamarbejde med Rusland eller Danmarks Arctic-5 samarbejde med Rusland om Polarhavet. I overensstemmelse med dets idealistiske politiske kultur vil Sverige gerne tale menneskerettigheder, herunder rettigheder for LGBTQ-personer, men det kan let opfattes som 'undergravende virksomhed' af Moskva.

\section{Efter Krim: de andre nordiske lande}

Opdelingen her mellem Norges og Finlands pragmatiske Ruslands-politikker og de - undertiden - mere værdibaserede tilgange i Sverige og Danmark kom tydeligt frem i den delvist fejlslagne nordiske manifestation i Kiev i 2014. Men efterhånden er opdelingen mellem de to sæt lande blevet noget sløret.

\footnotetext{
${ }^{20}$ Se Hamilton (2015). De baltiske lande har imidlertid udtrykt bekymring for, at en uklar skelnen mellem medlemmer og partnere kunne underminere troværdigheden af NATOs art. 5.

${ }^{21}$ Selv hvis Sverigedemokraterna (SD) skulle erstatte Moderaterna og blive det næststørste parti efter næste valg, ses de ikke som det 'gode selskab' og vil næppe blive tildelt en rolle i dette spørgsmål (partiet er i øvrigt ganske skeptisk vedrørende NATO-medlemskab).
} 
De norsk-russiske relationer forsures

Sverige er ikke det eneste land, der oplever spændinger i forhold til Rusland. Da EU besluttede sig for sanktioner mod Rusland efter Krim og hybridkrigen i Østukraine, fulgte Norge efter og besluttede de samme handelssanktioner og indrejseforbud til Norge for udvalgte russiske myndighedspersoner. Sammen med russiske modsanktioner kom dette i nogen grad til at hæmme grænsesamarbejdet i Nordområderne, meget til nordnorske politikeres utilfredshed.

Forudsigeligt nok skabte det også vrede i Rusland. Dmitrij Rogozin, daværende russisk vice-premierminister og en velkendt høg, var omfattet af indrejseforbuddet. Ifølge Svalbard-traktaten fra 1925 (Universitetet i Oslo, 2014) har Norge 'fuld suverænitet' over øgruppen, men borgere fra traktatmagterne, herunder Rusland, kan frit rejse til Svalbard (som ikke er omfattet af Schengen-reglerne) og bedrive 'fredelig virksomhed'. Ikke desto mindre informerede den norske regering den russiske ambassade om, at indrejseforbuddet mod udvalgte russere også omfattede Svalbard. Det russiske svar på dette skridt var at sende Rogozin til Svalbard (april 2015), hvorfra han sendte adskillige tweets på engelsk med tilhørende selfies, så besøget ikke ville gå upåagtet hen. Det gjorde det heller ikke i den norske regering, som reagerede ved at indføre yderligere restriktioner, som ikke er uproblematiske i forhold til den eksisterende traktat. Den russiske ambassadør i Oslo udtalte i den anledning, at sagen ikke kunne ses isoleret, men ville skade det bilaterale forhold i bredere forstand.

Rusland har besvaret indrejseforbuddet for udvalgte russere med et tilsvarende indrejseforbud til Rusland for udvalgte nordmænd. Da Stortingets udenrigs- og forsvarsudvalg skulle besøge den russiske Duma i februar 2017, kom det frem, at to af dets fem medlemmer var omfattet af forbuddet. På denne baggrund besluttede udvalget at aflyse sit besøg.

Det russiske udenrigsministerium protesterede, da Norge var vært for et seminar i regi af NATOs parlamentarikerforsamling på Svalbard i maj 2017. Ifølge den russiske protest var mødet i strid med 'ånden' i Svalbard-traktaten, ifølge hvilken Norge skal sikre, at der kun drives fredelig virksomhed på øgruppen (High North News, 2017). Et tilsvarende seminar blev holdt i 2004 uden russisk protest, men dengang i et bedre bilateralt klima. Generelt modsætter Rusland sig en rolle for NATO i Arktis.

Som reaktion på Krim og Ruslands militære selvhævdelse har Norge annulleret det meste af sit forsvarssamarbejde med Rusland i nordområderne. Grænsekontrollen er blevet forbedret, og et antal militære nyanskaffelser planlægges, såsom de dyre anti-ubåds P8A Poseidon kampfly. Siden slutningen af 2016 er norsk forsvar blevet forstærket med tilstedeværelsen af 330 amerikanske marinere i Trøndelag i Midtnorge. De er der angiveligt på 'rotationsbasis' (Haugevik \& Sending, 2018, s. 371), men denne retoriske formulering slører det faktum, at Norge er godt på vej til at revidere sin selvpålagte basepolitik: 'ingen udenlandske baser på norsk territorium i fredstid'.22 Som et vigtigt bidrag til NATO har Norge markant øget sin

\footnotetext{
${ }^{22}$ Dette benægtes dog i regeringens udenrigs- og sikkerhedspolitiske rapport til Stortinget 2017; se Norges regering (2017).
} 
overvågningskapabilitet $\mathrm{i}$ forhold til Kola-halvøen og den russiske nordflåde $\mathrm{i}$ kraft af et moderniseret Marjata, et elektronisk efterretningsskib stationeret i Kirkenes.

Dansk-russiske relationer: stadig nogenlunde

I EU har den danske profil vedrørende sanktioner mod Rusland ligget omtrent halvvejs mellem pragmatiske tyskere og stålsatte svenskere og polakker. Som resultat af NATOs topmøde i Warszawa har Danmark sendt 200 mand til at være del af en britisk ledet bataljon i Estland i tillæg til bidraget til den baltiske luftovervågning. På trods af dette har de dansk-russiske relationer været tålelige. I modsætning til Norge ønsker Danmark ikke en rolle for NATO i Arktis, da dette kunne øge spændingerne i forhold til Rusland (Kunz, 2018, s. 11-12).

To spørgsmål er vigtige for det fremtidige bilaterale forhold: 1) en dansk tilladelse til at Nord Stream 2 gasledningen kan gå gennem dansk territorialfarvand eller økonomisk zone og 2) dansk aktiv flådedeltagelse i NATOs ballistiske missilforsvar. Skulle Danmark beslutte sig mod russiske interesser i begge disse spørgsmål, vil det bilaterale forhold blive markant forringet.

Den russiske ambassadør i København har signaleret den alvor, hvormed Rusland ser på missilsagen: danske skibe udstyret med radar eller andre instrumenter, der servicerer missilforsvaret, vil blive udsat for atomvåbenangreb i krigstilfælde (Berlingske, 2015). Denne udtalelse chokerede danske politikere og kommentatorer, skønt dens logik ikke kom som den store overraskelse for militære eksperter. ${ }^{23}$

Både Rusland og Tyskland ønsker naturligt nok, at Danmark skal acceptere rørledningen, og Danmark ville sikkert have fået samme påskønnelse fra Rusland som i tilfældet med Nord Stream 1 i 2009, hvis man havde truffet en hurtig, positiv beslutning. På den anden side lobbyer Ukraine, Polen og de baltiske lande energisk i København for en afvisning, idet de angiveligt frygter russisk gasafpresning i fremtiden. ${ }^{24}$ De støttes af USA, som i lighed med de øvrige henviser til, at Ukraine vil miste gasindtægter fra de eksisterende gasledninger gennem landet som resultat af Nord Stream 2.

Udsat for dette krydspres har Danmark trukket en beslutning i langdrag og har også forsøgt at 'eksportere' beslutningen til EU-kommissionen i håb om, at rørledningen ville stride mod EU's fælles energipolitik (det Tredje Gasdirektiv). Danmark synes dog ikke at kunne slippe for beslutningen, uanset hvor mange gange man sparker bolden til 'hjørne'. ${ }^{25}$ Selv i dansk økonomisk zone, hvor Danmark ikke kan sige nej, men blot skal sikre den miljømæssigt bedste løsning, er der muligheder for at

\footnotetext{
${ }^{23}$ Den russiske ambassadør i Oslo har anvendt tilsvarende sprogbrug i forhold til mulig norsk deltagelse i NATOs missilforsvar. Se Arktisk Nyt (2017).

${ }^{24}$ Dette er næppe noget sagligt holdbart argument som argumenteret afTim Boersma. Se Brookings (2015).

${ }^{25}$ I februar 2019 udvidede EU-institutionerne direktivet, så det også omfatter eksterne rørledninger, dvs. rørledninger fra et EU-land til omverdenen (som Nord Stream 2). Dette vil dog næppe fritage Danmark for en beslutning (DIIS, 2019).
} 
trainere sagen. En ny rute, som vil kræve længerevarende undersøgelser, blev f.eks. foreslået, da den første ansøgning var lige ved at være færdigbehandlet.

Selvom det kan lyde paradoksalt har den dystre sikkerhedspolitiske udvikling i Danmarks nærområde i virkeligheden styrket landet politisk (selvom det ikke siges højt). Det afgørende er at sikre sig amerikansk engagement i det danske nærområde. I det mindste indtil valget af Donald Trump syntes Danmark på vej tilbage til de 'gode gamle dage' i halvfemserne med en Washington-København-Riga akse, hvor Danmark i midten kunne gøre sig politisk nyttig og også yde et substantielt bidrag til baltisk sikkerhed.

Finsk-russiske relationer: fortsat pragmatisme

Finland har udtrykt kritik af annekteringen af Krim og Ruslands involvering i Østukraine ligesom de andre nordiske lande. Som EU-medlem deltager Finland naturligvis i sanktionerne mod Rusland, skønt de har skadet den finske økonomi mere end de fleste andre europæiske landes (Euractiv, 2014). NORDEFCO-samarbejdet og det bilaterale samarbejde med Sverige er intensiveret med lettere adgang til brug af hinandens baser og luftrum, fælles ubådsjagt, efterretningsudveksling, fælles overvågningsoperationer m.v. Den finske grænsevagt, en særlig enhed under Indenrigsministeriet, er blevet autoriseret til at imødegå hybrid krigsførelse, som den sås under Krim-krisen (Barents Observer, 2014). Udenrigsministeriet rekvirerede en international ekspertrapport om konsekvenserne af et muligt finsk NATO-medlemskab. ${ }^{26}$ En konklusion var, at hvis Finland og Sverige skulle tilslutte sig NATO, burde det ske 'hånd i hånd'. Finland alene ville næppe give mening af rent logistiske grunde, ${ }^{27}$ og Sverige alene ville føre til kompenserende russisk pres på Finland.

Finland har imidlertid undgået den russiske dybfryser, som de tre andre lande har oplevet i kortere eller længere perioder. Dette skyldes formentlig landets pragmatiske politiske kultur og tilgang til Rusland. Udsat for ret så utilslørede russiske trusler om konsekvenserne af et NATO-medlemskab har finske politikere - i modsætning til deres svenske kolleger - formået at tie stille. Finland har holdt kommunikationslinjerne åbne til Moskva, ${ }^{28}$ og Putin har f.eks. flere gange besøgt Helsingfors.

\section{Donald Trump indtager scenen}

Under den Kolde Krig blev det mindste tegn på supermagtsafspænding mødt med nordisk applaus. Valget af Donald Trump til amerikansk præsident gav et løfte om

\footnotetext{
${ }^{26}$ Konsekvenserna av ett eventuellt finskt NATO-medlemskap, Helsingfors: Utrikesministeriet, april 2016.

${ }^{27}$ Eftersom transport gennem Nordnorge næppe er en mulighed, vil NATO-forstærkninger til Finland være et lige så stort problem som til de baltiske lande i dag.

${ }^{28}$ Den finsk-russiske handelskommission mødtes i november 2016 for første gang siden annekteringen af Krim. Se Financial Times (2016).
} 
bedre russisk-amerikanske relationer, baseret såvel på hans valgkampagne som udtalelser i embedet. Men det nordiske bifald udeblev. Hvad skyldes det?

Der er adskillige aspekter af Trumps 'program', der har direkte relevans for de nordiske lande og deres forhold til Rusland:

- Trumps betoning af geoøkonomi på bekostning af universelle værdier betyder, at rygstødet bag de nordiske landes internationale værdipolitik, bl.a. i forhold til Rusland, er forsvundet.

- Trump støtter eksplicit amerikansk unilateralisme eller bilateralt diplomati på bekostning af multilateralisme, en hjørnesten i de nordiske landes udenrigspolitikker - bl.a. som instrument til at indbinde Rusland.

- Som det tredje og vigtigste: Trumps positive vurdering af Putin, kombineret med hans kritik af amerikanske allierede for at køre på frihjul i NATO, har skabt en frygt for et amerikansk-russisk kondominium hen over hovedet på landene i den nordisk-baltiske region: en frygt for at blive svigtet til forskel fra den Kolde Krigs frygt for at blive inddraget i amerikanernes krig ('fear of abandonment' modsat 'fear of entrapment', Snyder, 1984). 'Skulle vi risikere 3. verdenskrig for en allieret, der ikke har ydet sin rimelige del af forsvarsbyrden?' spurgte Trump retorisk. Generelt er småstaternes strategiske ressourcer, som er værdifulde under stormagtskonflikt og konkurrence, værdiløse i tilfælde af stormagtssamarbejde eller endog kondominium (Mouritzen, 1991).

Naturligvis har udenrigs- og forsvarsministre eller sikkerhedsrådgivere, tiltrædende og afgående, giort, hvad de kunne for at berolige USA's allierede (Heisbourg, 2017, s. 10), og den amerikanske kongres har gjort sit bedste for at vedligeholde amerikansk-russiske udeståender. USA er næppe længere en enhedsaktør, og i alle tilfælde mangler et amerikansk lederskab i NATO, for at sige det mildt. USA's nordiske allierede har stået i det samme dilemma som allierede i resten af verden af formen: 'skal vi imødekomme Trump og kraftigt øge vore forsvarsbudgetter på bekostning af andre udgifter, eller skal vi søge efter alternative sikkerhedspolitiske løsninger (eller både og)?' Og de nordiske ikke-allierede har spurgt sig selv: 'skal vi virkelig tilslutte os en alliance med tvivlsom beskyttelse og utroværdigt lederskab? Er prisen værd at betale?'

\section{Danmark og Norge forsøger at behage Trump}

I danske regeringskredse var den umiddelbare reaktion på Trump-fænomenet en blanding af benægtelse og forvirring. Forventningen, som i dag tager sig ud som ønsketænkning, var, at Trump ville blive normaliseret af 'Washington-systemet'. Regeringens udenrigs- og sikkerhedspolitiske strategi for 2017-18, offentliggjort i juni 2017, var en øvelse i afdramatisering. ${ }^{29}$

\footnotetext{
${ }^{29}$ Navnet 'Trump' bliver end ikke nævnt. 'Det er endnu for tidligt at vurdere, hvordan amerikansk udenrigspolitik vil tegne sig i de kommende år' (s. 6). Se Danmarks regering (2017).
} 
I strategien for 2019-20 (Danmarks regering, 2018) kritiserer Danmark imidlertid Trumps tilbagetrækninger fra flere multilaterale aftaler (om klima, Iran og handel) og dermed fra det globale lederskab, som Danmark har draget fordel af. Danmark bør søge at fremme amerikansk forståelse af fordelene ved en multilateral verdensorden, også for USA selv (igen ønsketænkning, virker det som). Med den lange liste af russiske 'synder', der listes i rapporten, er det desto vigtigere at 'række ud' (rapportens formulering) til USA for at bibeholde dets engagement i NATO.

Skønt Danmark har imødekommet USA ved at deltage i næsten enhver militær ekspedition efter den Kolde Krig, var forsvarsbudgettet i 2017 faldet til 1,14\% af BNP - langt fra det 2\%'s mål, som NATO-medlemslandene lovede hinanden ved Wales-topmødet i 2014 (Ringsmose \& Henriksen, 2017). Politikerne forsøgte at mildne den amerikanske utilfredshed gennem forsvarsaftalen i januar 2018, som betød, at det danske budget ville stige til 1,3\% af BNP pr. 2023. Det hjalp dog ikke. Derfor vedtoges en ekstraordinær tillægsaftale kun 12 måneder senere, som betyder at tallet nu vil være 1,5\% pr. 2023, både baseret på flere penge og reviderede statistiske principper (Altinget, 2019). Regeringen har end ikke forsøgt at skjule, at dette tillæg skyldes amerikansk pres snarere end ændringer i trusselsbilledet i de 12 måneder siden forsvarsaftalen. Statistik og dets præsentation har sjældent eller aldrig været vigtigere i dansk forsvarspolitik.

En plan B med en nordisk eller europæisk forsvarsunion, hvis Trump skulde melde USA ud af NATO, er ikke blevet luftet; NATOs undergang kunne let blive en selvopfyldende profeti med offentlige spekulationer af denne art. Alligevel omtaler regeringens 2017-18 strategi et behov for en 'styrkelse af det nordiske samarbejde samt af samarbejdet med de øvrige alliancepartnere i Østersøregionen, blandt andet gennem det planlagte bidrag til NATOs fremskudte tilstedeværelse i de baltiske lande' (s. 15). I 2019-20 strategien gentages behovet for sikkerhedspolitisk samarbejde med de andre Østersølande, uden at det rent nordiske samarbejde nævnes. Planer om fornyet europæisk forsvarssamarbejde gives betydelig vægt, men kun som bidrag til atlantisk byrdefordeling. Den danske EU-undtagelse på forsvarsområdet beklages, men der nævnes ingen planer om en folkeafstemning, der kunne afskaffe undtagelsen.

Med det forringede forhold til den russiske stormagt var en ustabil og uforudsigelig amerikansk administration ikke just ønskedrømmen i Oslo. Som den danske regering forsøgte den norske imidlertid at etablere de tættest mulige bånd til Washington. Skønt Norge havde lovet gradvis at øge sit forsvarsbudget $-1,62 \%$ af BNP i 2017 - i retning af $2 \%$ i løbet af det næste årti, modtog den norske regering som den danske et brev i sommeren 2018, der forlangte forøgede forsvarsudgifter.

Regeringens udenrigs- og forsvarspolitiske rapport fra april 2017 (Norges regering, 2017) til Stortinget var ganske lakonisk i spørgsmålet om ændringer i amerikansk udenrigspolitik. ${ }^{30}$ I tillæg til at betone NATO og USA som hjørnestenene

\footnotetext{
${ }^{30}$ Men der blev stillet i udsigt, at en separat rapport om det langsigtede forhold til USA ville komme senere. Løftet er dog endnu ikke indfriet.
} 
i norsk sikkerhedspolitik fremhævedes tætte bilaterale sikkerheds- og forsvarsbånd med udvalgte europæiske allierede (UK, Tyskland, Frankrig og Holland) og med to partnerlande (Sverige og Finland). Norge ville tage initiativ til regelmæssige konsultationer mellem NATO og de to partnere (s. 31). Generelt er målet at 'trappe opp den sikkerhetspolitiske dialogen og samarbeidet i Norden' (s. 7). Som det fremgår, gives nordisk samarbejde en højere prioritet i den norske rapport end i de to danske strategier.

Upåvirket af Trump er de norsk-russiske relationer fortsat anspændte. Rusland arresterede Frode Berg, som erkendte sig skyldig i spionage, i december 2017, mens Norge arresterede Mikhail Boshkarev i september 2018, også for spionage (han blev dog løsladt i oktober). ${ }^{31}$ NATOs 'Trident Juncture' øvede kollektivt forsvar i oktobernovember 2018 i det centrale og østlige Norge. Dette var den største øvelse af sin art i Norge siden den Kolde Krig.

\section{Sverige i en blindgyde}

Kort før valget af Donald Trump (august 2016) havde USA's vicepræsident Joe Biden besøgt Stockholm og offentligt formuleret, hvad der reelt var en bilateral amerikansk beskyttelsesgaranti af svensk territorium. ${ }^{32}$ Med Trumps skiftende syn på den slags forpligtelser, selv i forhold til NATO-allierede, er værdien af Bidens garanti højst tvivlsom (skønt landenes forsvarsministre mødtes i sommeren 2018; Fägersten \& Jerdén, 2018, s. 348).

Opinionsundersøgelser i Sverige vedrørende ønskeligheden af NATO-medlemskab viser konsekvent et nej-flertal. ${ }^{33}$ Dette er væsentligt, eftersom svenske vælgere er blevet lovet, at et muligt medlemskab skal bekræftes i en folkeafstemning. Vælgernes respekt for den traditionelle alliancefrihed blev kortvarigt brudt i kølvandet på Krim-konflikten. ${ }^{34}$ Men nu, med Donald Trumps massive upopularitet blandt svenskere, er pendulet svinget tilbage. ${ }^{35}$ Blandt andet derfor, men også fordi en folkeafstemning angiveligt ville splitte landet og bane vej for fjendtlige cyberangreb og 'fake news', var status quo at foretrække ifølge forsvarsminister Peter Hultqvist. ${ }^{36}$

Hertil kommer, at Sverige støttede et generelt forbud mod kernevåben ved en afstemning i FN's Generalforsamling (til forskel fra NATO-medlemmerne og Finland, f.eks.) Dette førte til en advarsel fra Pentagon til det svenske forsvarsministerium

\footnotetext{
${ }^{31}$ Sidstnævnte episode skabte vrede hos den russiske udenrigsminister Lavrov, se Associated Press (2019).

32 'Ingen ska kunna missförstå, varken herr Putin eller någon annan, att detta är okränkbart territorium. Punkt. Punkt. Punkt.' Se Aftonbladet (2016).

${ }^{33}$ F.eks. 35\% for og 46\% imod, 7.-12. juni 2017 (SIFO). Se Svenska Dagbladet (2017).

${ }^{34}$ Den eneste tilgængelige SIFO-måling med ja-flertal - 41\% ja og 39\% nej - blev udført 2.-8. september 2015. Se Svenska Dagbladet (2015).

${ }^{35}$ Dette skete dog allerede i 2016 , som det fremgik af en måling i juli det år.

${ }^{36}$ The Leangkollen Security Conference, 13.-14. februar 2017, se Atlanterhavskomiteen (2017).
} 
(august 2017): skulle Sverige ratificere forbudstraktaten, ville det have 'negative konsekvenser for svensk-amerikansk politisk, militært og industrielt samarbejde' (OSW, 2017) - og udelukke NATO-medlemskab, kan man formode. Sagen er nu blevet udskudt ved nedsættelse af en kommission. Men den har fremkaldt en offentlig uenighed mellem Margot Wallström (for traktaten) og Peter Hultqvist (imod).

Så alt i alt er svensk sikkerhedspolitik havnet i en blindgyde, fanget i en kombination af en frossen konflikt med Rusland og manglende alliance-beskyttelse. Sverige har frivilligt forpligtet sig på de baltiske landes sikkerhed ${ }^{37}$ uden at få NATOs beskyttelsesgaranti (artikel 5 i NATO-traktaten) til gengæld. Østersøen er ikke længere en effektiv voldgrav.

\section{Finland mindre sårbar i forhold til Trump-effekten}

En tilsvarende 'Trump-effekt' kan ikke observeres i Finland, af den simple grund at finsk opinion altid har været markant imod NATO-medlemskab; ja-andelen overstiger sjældent 20\%). ${ }^{38}$ Men også det faktum, at Finland militært er mere selvhjulpent end Sverige, gør landet mindre sårbart over for svingninger i amerikansk sikkerhedspolitik.

Præsident Ninistö luftede offentligt i starten af 2017 muligheden for et TrumpPutin topmøde i Helsingfors. Politiske kontakter med Rusland er fortsat på alle niveauer; f.eks. besøgte Putin Helsingfors i juni 2017 som del af fejringen af den finske stats 100-års jubilæum. I juli 2018 blev Trump-Putin topmødet omsider holdt i Helsingfors. Dette var i sig selv en betydelig sejr for finsk diplomati. Substantielt bar Ninistös forsøg på at rette gæsternes opmærksomhed mod Østersøregionen dog ikke frugt at dømme ud fra deres fælles pressekonference. ${ }^{39}$

\section{Trump-paradokset}

Der er et indbygget paradoks i Trumps tilgang til de nordiske lande og deres Ruslands-relationer. Hvis Trump havde abonneret på opfattelsen af Rusland som 'ondskabens imperium', ville hans bestandige krav til sine europæiske allieredes forsvarsudgifter følge logisk. Der er en modsigelse mellem budgetpresset og hans udogmatiske, næsten positive opfattelse af Rusland og Putin. Trumps motiv synes at handle om geoøkonomi (NATO-byrdefordeling) af formen: 'Vi, USA, ønsker ikke at blive økonomisk udnyttet længere!'

Trump kan således ikke beskyldes for den generelle forværring af de nordiskrussiske relationer; den skyldes de rent regionale dynamikker. De eneste kendte

\footnotetext{
${ }^{37}$ I Mike Winnerstigs formulering: 'Every imaginable military conflict in the Baltic Sea area would lead to Sweden's territory being much coveted by the warring parties, especially for operations directed at the Baltics.' Se Wiklund et al. (2017).

${ }^{38}$ F.eks. $21 \%$ ja mod $51 \%$ nej, 15 . februar 2017. Selv under forudsætning af at Sverige tilslutter sig, var der nej-flertal, om end mindre: $38 \%$ ja mod $44 \%$ nej. Se Yle (2017).

${ }^{39}$ 16. juli 2018. Se The Guardian (2018).
} 
sager, hvor den amerikanske administration har forsøgt at påvirke nordiske udenrigspolitikker, har været den danske beslutning om Nord Stream 2 og den svenske ratificering af et generelt forbud mod kernevåben. Kun den første har noget at gøre med Ruslands-politik og er formentlig begrundet mere i geoøkonomi, det amerikanske ønske om at sælge flydende naturgas til Europa, end i frygt for Rusland.

Men Trump-fænomenet har også sine utilsigtede konsekvenser. Den vigtigste er, at Sverige er havnet i en sikkerhedspolitisk blindgyde (dog delvis selvforskyldt). En fremtidig utilsigtet konsekvens kunne være, at øgede danske og norske forsvarsudgifter, der skal tilfredsstille Trump, skaber yderligere spændinger i deres Ruslands-relationer og i regionen som helhed. Det vil navnlig afhænge af, hvilken type våbenudstyr bevillingerne bruges til.

\section{Russisk 'del og hersk'?}

Som nævnt er 'del og hersk' (divide et impera) en klassisk (geo)politisk strategi. Ved at slå en kile ind mellem svagere parter ved hjælp af pisk og gulerod kan den stærkere part sikre sig, at de ikke danner en samlet front mod den. 'Del og hersk' er på ingen måde en russisk specialitet, men et typisk stormagtsinstrument i forhold til en gruppe af sammenlignelige lande, der normalt tilhører samme region.

Har Rusland praktiseret 'del og hersk' blandt de nordiske lande for at forhindre en nordisk front mod Rusland? Dette er selvsagt vanskeligt at bevise, eftersom denne type strategi sjældent eller aldrig vedgås offentligt, men typisk er en strategi, der tilskrives andre. ${ }^{40}$ Men timingen i forværring eller forbedring af de individuelle Ruslands-relationer kan give et fingerpeg. Vi har således set, at de svensk-russiske relationer var favorable, så længe Danmark var i den russiske dybfryser mellem 2002 og 2008. Men så, da det svensk-russiske forhold pludselig forringedes fra 2008, forbedredes det dansk-russiske forhold markant. Samtidig havde Norge og Finland ganske gode relationer med Rusland. En dristig hypotese kunne være, at der kun er plads til ét nordisk land ad gangen i den russiske 'straffeboks'. Så nu, da det norsk-russiske forhold er forringet (siden 2015 og yderligere i foråret 2017), er det næppe nogen tilfældighed, at det første bilaterale møde mellem Sergei Lavrov og Margot Wallström blev afholdt (Moskva, februar 2017). Ved den efterfølgende fælles pressekonference udtrykte Lavrov håbet, at 'Deres besøg her vil hjælpe med til at overvinde, hvad der ikke har været den bedste periode i de russisk-svenske relationer og vil skitsere yderligere skridt i retning af at genoprette [...] relationer til gavn for begge parter' (Tass, 2017). I oktober 2017 opfordrede den russiske ambassadør i et avisinterview de to lande til at 'make peace in their heads' (Kunz, 2018, s. 6).

\footnotetext{
40 'Del og hersk' er derfor heller ikke en strategi, en politiker kan formodes at stå ved i et interview. 'Even if we have the divide and rule principle on our mind, we're not so naïve as to develop any schemes on that basis...if our partners feel that Russia is really after this, it would do nothing but unite them' (Russian deputy foreign minister Ryabkov). Se Russia Beyond (2008).
} 
Det ville være en overdrivelse at sige, at disse forhåbninger er gået i opfyldelse, men kontakter mellem de to udenrigsministre blev opretholdt under det svenske medlemskab af FN's Sikkerhedsråd 2017-18, hvor emner på rådets dagsorden var et naturligt samtaleemne. I april 2019 mødtes statsminister Löfven med Putin i tilknytning til et internationalt arktisk forum i St. Petersborg. Formentlig har også svenskerne været interesserede $\mathrm{i}$ en optøning af forholdet og at komme ud af den sikkerhedspolitiske blindgyde.

\section{Er Rusland for vigtigt til en fælles nordisk politik?}

Den historiske analyse af nordisk samarbejde og dets barrierer viser, at bilaterale relationer med en stormagt ofte har været for vigtige til nordisk samarbejde, for ikke at tale om en fælles nordisk politik. Til trods for en amorf folkelig nordisme har egeninteressen $\mathrm{i}$ hver hovedstad altid sejret. Interesse i dybere nordisk udenrigs- og sikkerhedspolitisk samarbejde har normalt været begrænset til en enkelt regering ad gangen - typisk den geopolitisk mest udsatte - mens de resterende har været mere eller mindre lunkne. Dette har enten skyldtes forskellige geopolitiske interesser eller, i nogle få tilfælde, idiosynkrasier med baggrund i forskellige tolkninger af den fælles historie.

Mere vidtgående samarbejde vil kræve nogenlunde ens opfattelser af trusler og muligheder. Dette er imidlertid præcis, hvad der kan skimtes i krystalkuglen. Ukrainekonflikten har ført til konvergerende opfattelser af geopolitiske interesser i de fire regeringer (en beskeden begyndelse kunne skimtes allerede efter Georgien-krigen). I fravær af idiosynkrasier vil dette styrke samarbejdet. Dette er historisk unikt. Hvad enten det er sagligt begrundet eller ej, opfatter alle fire lande, med Danmark som en delvis undtagelse, Rusland som truende. De er udsat for næsten-krænkelser af deres luftrum og angreb i cyberspace. Finland har en lang grænse med Rusland, og svenske eksperter er optaget af Gotlands-scenariet. Norge grænser op til Kola-halvøen, base for den russiske nordflåde, og oplever et forringet forhold til den store nabo. Derfor vil det sikkerheds- og forsvarspolitiske samarbejde mellem disse tre lande blive intensiveret. Denne proces vil også omfatte Danmark, hvis Rusland skulle blive en seriøs trussel mod Bornholm (fra f.eks. Iskander missilsystemet i Kaliningrad). Man vil stadig stole på NATO, men nordisk samarbejde vil i så fald sejle op som et vigtigt supplement.

Vidtgående samarbejde og koordination er imidlertid ikke ensbetydende med en fælles politik. Den fælles kronik af de nordiske forsvarsministre i 2015, i sig selv en diplomatisk bedrift, er formentlig det længste, hovedstæderne kan gå bedømt ud fra den historiske erfaring. Og kronikken handlede jo, ret beset, mere om det russiske 'synderegister' end om, hvordan man i fællesskab skulle reagere på det. I et visionspapir for nordisk forsvarssamarbejde fra november 2018 (Vision, 2025) operationaliseres landenes indbyrdes solidaritetsbestræbelser, men stadig under hensyntagen til deres nationale suverænitet, geopolitiske forskelle og eksisterende (NATO-) forpligtelser. 
Trump-fænomenet har ikke ført de to nordiske NATO-medlemmer til at kaste sig i armene på sine nordiske eller europæiske partnere; Norge og Danmark har gjort deres bedste for at imødekomme Trumps budgetkrav som del af en 'fear of abandonment'. Forringelsen af nordisk-russiske relationer - nogle mere end andre - har intet med Trump at gøre. Det eneste offentligt kendte amerikanske pres, der har med Rusland at gøre, er i forhold til Danmarks Nord Stream 2-beslutning. Men der er uintenderede konsekvenser af Trump-faktoren. Sverige er havnet i en sikkerhedspolitisk blindgyde (der dog også skyldes andre forhold). Der kan også være fremtidige uintenderede konsekvenser for de nordiske Ruslands-relationer af de forøgede forsvarsudgifter i disse år.

\section{Om forfatteren}

Hans Mouritzen har udviklet teori om flere beslægtede emner: internationale organisationers autonomi, småstatspolitik og dens rumlige forudsætninger, hvordan ekstern fare påvirker internt sammenhold, og hvordan historisk erindring indvirker på nutidens udenrigspolitiske beslutninger ('fortidens skygge').

\section{Litteratur}

Aftonbladet (2016, 25. august). Joe Biden hyllade Sverige - och varnade Ryssland. Hentet 28. juni 2019 fra http:/www.aftonbladet.se/nyheter/article23403260.ab

Altinget (2019, 31. januar). Lang vej til Washington bliver tilfreds. Hentet 28. juni 2019 fra https://www. altinget.dk/forsvar/artikel/stadig-lang-vej-til-washington-bliver-tilfreds

Arktisk Nyt (2017). Russisk ambassadør truer: Glem fredeligt Arktis. Hentet 8. august 2019 fra http://www. arktisknyt.dk/2017/03/23/russisk-ambassadoer-truer-glem-fredeligt-arktis/

Associated Press (2019, 25. september). Russia's Lavrov lashes out at Norway arrest of suspected spy. Hentet 28. Januar 2019 fra https://www.apnews.com/392110aeb1194eb89c749b7e9e93f00e

Atlanterhavskomiteen (2017). Hentet 28. juni 2019 fra http://www.atlanterhavskomiteen.no/nettsider/dnak/ leangkollen $/ 2017$

Bailes, A. (2016). Denmark in Nordic cooperation: Leader, player, sceptic. I H. Mouritzen \& N. Hvidt (Red.), Danish Foreign Policy Yearbook 2016 (s. 31-51). København: DIIS.

Barents Observer (2014, 1. august). Finnish border guards would be authorized to counter hybrid warfare. Hentet 3. august 2017 fra https:/thebarentsobserver.com/en/borders/2017/08/finnish-border-guardcould-be-authorized-counter-hybrid-warfare

Berlingske (2014, 5. marts). Lidegaard: bevægende at være på Maidan. Hentet 30. juni 2019 fra https://www. berlingske.dk/internationalt/lidegaard-bevaegende-at-vaere-paa-maidan-i-kiev

Berlingske (2015, 26. marts). Det er ikke en trussel. Det er en advarsel. Hentet 8. august 2017 fra https:// www.b.dk/globalt/det-er-ikke-en-trussel.-det-er-en-advarsel.

De Briganti, G. (2013, 9. december). Why Norway pulled the plug on Archer, Hentet 30. Juni 2019 fra http:// www.defense-aerospace.com/articles-view/feature/5/150076/archer\%3A-why-norway-pulled-the-plug. html

Brookings (2015, 28. oktober). Forget Russia, European energy security begins at home. Hentet 28. Juni 2019 fra https://www.brookings.edu/blog/order-from-chaos/2015/10/28/forget-russia-european-energysecurity-begins-at-home/

Brundtland, A. O. (1966). Nordisk balanse før og nå. Internasjonal Politikk, 25(5), 491-541.

Crawford, T. (2011). Preventing enemy coalitions. How wedge strategies shape power politics. International Security, 35(4), 155-89.

Dagens Nyheter (2015, 1. marts). Mordet förstärker bilden av Putins skräckvälde. Hentet 23 juli 2017 fra http://www.dn.se/arkiv/nyheter/mordet-forstarker-bilden-av-putins-skrackvalde/ 


\section{Hans Mouritzen}

Dahl, A. (2014). NORDEFCO and NATO: "Smart defence" in the North?, Research Paper no. 101. Rom: NATO Defense College.

Danmarks regering (2017). Udenrigs- og sikkerhedspolitisk strategi 2017-2018. København: Det danske udenrigsministerium. Hentet 28. juni 2019 fra https:/www.regeringen.dk/media/3550/udenrigs-ogsikkerhedspolitisk-strategi.pdf

Danmarks regering (2018). Udenrigs- og sikkerhedspolitisk strategi 2019-2020. København: Det danske udenrigsministerium. Hentet 28. juni 2019 fra http:/um.dk/da/udenrigspolitik/aktuelle-emner/udenrigsog-sikkerhedspolitisk-strategi-2019-20/

DIIS (2019). Danmark og spillet om Nord Stream 2. Policy brief. Hentet 1. juli 2019 fra https://www.diis.dk/ publikationer/danmark-spillet-nord-stream-2

Euractiv (2014, 6. august). Finland warns Russia sanctions could spell 'economic crisis'. Hentet 28. Juni $2019 \mathrm{fra} \mathrm{http://www.euractiv.com/section/europe-s-east/news/finland-warns-russia-sanctions-could-spell-}$ economic-crisis/.

Fägersten, B. \& Jerdén, B. (2018). En moralisk stormakt i post-neutral tappning: Svensk utrikespolitik 2011-2018. Internasjonal Politikk, 76(4), 343-54.

Financial Times (2016, 30. november). Norway and Finland thaw relations with Russia. Hentet 28. Juni 2019 fra https://www.ft.com/content/269a73e4-b70b-11e6-ba85-95d1533d9a62

Fogh Rasmussen, A. (2002, 5. november). Zakajev: Opgøret med dansk tilpasning. Politiken.

Guardian (2018, 17. juli). Helsinki summit: What did Trump and Putin agree? Hentet 28. juni 2019 fra https:// www.theguardian.com/world/2018/jul/17/helsinki-summit-what-did-trump-and-putin-agree

Gebhard, C. (2013). Soft Competition: Finland, Sweden and the Northern dimension of the European Union. Scandinavian Political Studies, 36(4), 365-90.

Hamilton, D. (2015). Rude awakening: Security challenges in Northern Europe. I H. Mouritzen \& N. Hvidt (Red.), Danish Foreign Policy Yearbook 2015 (25-50). København: DIIS.

Haugevik, K. \& Sending, O. J. (2018). Norske svar på internasjonale utfordringer: Retorisk endring, stabilitet i tiltak. Internasjonal Politikk, 76(4), 366-383.

Heisbourg, F. (2017). The emperor vs the adults: Donald Trump and Wilhelm II. Survival, 59(2), 7-12.

High North News $(2017,12$. maj). Security implications in focus at NATO PA's Svalbard meeting. Hentet 28. Juni 2019 fra http://www.highnorthnews.com/security-implications-in-focus-at-nato-pas-svalbardmeeting/

Historieportalen (2019). Det storpolitiske spil. København: Gyldendal. Hentet 28. juni 2019 fra http:// historieportalen.gyldendal.dk/forloeb/besaettelsestiden/kapitel-2/kapitler/det_storpolitiske_spil_den_9_ april_1940.aspx)

Iso-Markku, T., Innola, E. \& Tiilikainen, T. (2018). A stronger North? Nordic cooperation in foreign and security policy in a new security environment. FIIA Report. Helsinki: Finnish Institute of International Affairs.

Kempf, O. (2012). Friends in need. The Swedish declaration of solidarity. Hentet 28. juni 2019 fra http://www. egeablog.net/index.php?post/2012/09/29/Friends-in-need.-The-Swedish-Declaration-of-Solidarity

Kragh, M. \& Åsberg, S. (2017). Russia's strategy for influence through public diplomacy and active measures: The Swedish case. Fournal of Strategic Studies, 40(6), 773-816.

Kunz, B. (2018). Northern Europe's strategic challenge from Russia. Russie.Nei.Visions, No. 111. Paris: Institut français des relations internationales.

Leraand, D. (2014). Skandinavisk forsvarsforbund. I Store norske leksikon. Hentet 28. juni 2019 fra https://snl. no/Skandinavisk_forsvarsforbund

Mellander, M. \& Mouritzen, H. (2016). Learning to assert themselves: Small states in asymmetrical dyads. Two Scandinavian dogs barking at the Russian bear. Cooperation and Conflict 51(4), 447-466.

Mouritzen, H. (1991). Tension between the strong, and the strategies of the weak. Fournal of Peace Research, 28(2), 217-231.

Mouritzen, H. (1997). Denmark in the post-Cold War era: The salient action spheres. I H. Mouritzen \& B. Heurlin (Red.), Danish Foreign Policy Yearbook 1997 (33-51). København: DIIS.

Mouritzen, H. (2006). The Nordic-Baltic area: Divisive geopolitics at work. Cambridge Review of International Affairs, 19(3), 495-511.

Mouritzen, H. \& Wivel, A. (2012). Explaining foreign policy. International diplomacy and the Russo-Georgian War. Boulder, CO: Lynne Rienner.

NB8 (2010). NB8 wise men report. Hentet 28. juni 2019 fra https://www.stjornarradid.is/media/utanrikisraduneyti-media/media/Skyrslur/NB8-Wise-Men-Report.pdf

Nexon, D. (2009). The balance of power in the balance. World Politics, 61(2), 330-59. 
Norges regering (2017). Veivalg $i$ norsk utenriks- og sikkerhetspolitikk. Hentet 29. juni 2019 fra https://www. regjeringen.no/no/tema/utenrikssaker/sikkerhetspolitikk/veivalg/id2470357/

NUPI (2018). After Crimea: The future of Nordic defence cooperation. Policy brief. Hentet 1. Juli 2019 fra https://www.researchgate.net/publication/327040031_After_Crimea_The_future_of_Nordic_Defence_ Cooperation_Policy_Brief

OSW (2017, 20. september). Aurora: Sweden's response to Zapad? Hentet 28. juni 2019 fra https://www.osw. waw.pl/en/publikacje/analyses/2017-09-20/aurora-swedens-response-to-zapad

Posner, E. A., Spier, K. E. \& Vermeule, A. (2009). Divide and conquer. Harvard Law and Economics Discussion Paper no. 639.

Pyykönen, J. (2016). Nordic partners of NATO: How similar are Finland and Sweden within NATO cooperation? FIIA Report 48. Helsinki: Finnish Institute of International Affairs.

Rahbek-Clemmensen, J. \& Thomasen, G. (2018) Learning from the Ilulissat Initiative. Rapport, Center for militære studier, Københavns Universitet.

Ringsmose, J. \& Henriksen, A. (2017). Trump, NATO og den europceiske sikkerhedsarkitektur. DIIS Rapport 2017:4. København: DIIS.

Russia Beyond (2008, 30. november). Moscow has no wish to 'divide and rule'. Hentet 28. Juni 2019 fra http:// rbth.co.uk/articles/2008/11/30/301108_wish.html

Saxi, H. L. (2011). Nordic defence cooperation after the Cold War. Oslo files on defence and security No. 1, Oslo: Norwegian Institute for Defence Studies.

Snyder, G. (1984). The security dilemma in alliance politics. World Politics, 36(4), 461-95.

Stoltenberg, T. (2009, 9. februar). Nordisk samarbeid om utenriks- og sikkerhetspolitikk. Hentet 28. juni 2019 fra https:/www.regjeringen.no/globalassets/upload/ud/vedlegg/nordiskrapport.pdf

Svenska Dagbladet (2014, 16. november). Ingen ska tvivla på at vi kräver respekt. Hentet 9. august 2017 fra https://www.svd.se/ingen-ska-tvivla-pa-att-vi-kraver-respekt

Svenska Dagbladet (2015, 13. september). Övervikt för Nato-medlemskap. Hentet 28. juni 2019 fra https:// www.svd.se/agrell-ansok-till-nato-med-finland

Svenska Dagbladet (2016, 19. maj). Ryssland kan ligga bakom sabotaget. Hentet 28. juni 2019 fra https://www. svd.se/terrorforskare-ryssland-kan-ligga-bakom-sabotaget

Svenska Dagbladet (2017, 30. juni). SvD/Sifo: Putin och Trump påverkar inte Nato-opinion. Hentet 28. Juni 2019 fra https://www.svd.se/putin-och-trump-paverkar-inte-svenskt-nato-opinion.

Sveriges regering $(2015,31$. august). Sveriges militära samarbete med USA måsta fördjupas. Hentet 9 . august 2017 fra http://www.regeringen.se/debattartiklar/2015/08/sveriges-militara-samarbete-med-usa-mastefordjupas/

Tass (2017, 21. februar). Lavrov voices hope for restoration of Russia-Sweden relations. Hentet 28. juni 2019 fra http://tass.com/politics/932070

TenYears On (2019). Reassessing the Stoltenberg report on Nordic cooperation. Hentet 30. juni 2019 fra https://www. diis.dk/en/research/10-years-on-reassesing-the-stoltenberg-report-on-nordic-foreign-affairs-cooperation

Universitetet i Oslo (2014). The Svalbard Treaty. Hentet 28. juni 2019 fra http://www.jus.uio.no/english/ services/library/treaties/01/1-11/svalbard-treaty.xml

Vision 2025 (2018). Nordic defence cooperation vision 2025. Nordiske forsvarsministre, Oslo. Hentet 30. juni 2019 fra https://www.defmin.fi/files/4401/Nordefco_Visio2025.pdf

Wammen et al. (2015, 10. april). Nordiske forsvar samarbejder. Fyllands-posten. Hentet 28. juni 2019 fra https:// jyllands-posten.dk/debat/breve/ECE7613497/Nordiske-forsvar-samarbejder/

Wigell, M. \& Vihma, A. (2016). Geopolitics versus geoeconomics: The case of Russia's geostrategy and its effects on the EU. International Affairs, 92(3), 605-27.

Wiklund, C. H. et al. (2017). Perspectives on national security in a new security environment, Strategic Outlook 7, Stockholm: FOI.

Yle (2017, 15. februar). Poll: Finns more uncertain over Nato membership. Hentet 28. juni 2019 fra https://yle. fi/uutiset/osasto/news/poll_finns_more_uncertain_over_nato_membership/9460839.

\section{Abstract in English \\ The Nordic countries interact with Russia not only in the Baltic Sea region, but also in the Barents region and in the Polar Arctic. In order to get a full picture of the underlying dynamics, individual Nordic Russia-relations should}


be studied in a comprehensive framework. Swedish-Russian, Danish-Russian, Norwegian-Russian, and Fenno-Russian relations have developed differently since about 2000. There are two barriers to Nordic security policy cooperation: (1) the countries' different geographical locations, and (2) various idiosyncrasies between pairs of Nordic countries, typically rooted in different interpretations of their common history. Thus, the Nordic soil has traditionally been fertile for great powers seeking to 'divide and rule', and Russia has apparently succeeded in this since about 2000. However, in the wake of Russia's involvement in the Ukraine conflict and the election of Donald Trump as US president, geopolitical interests seem to be converging with fairly even threat perceptions being found in Nordic capitals. In the absence of idiosyncrasies, this will strengthen security and defence cooperation, although a common Nordic Russia-policy will not materialize. All four countries, in particular Sweden, face difficult dilemmas in this new situation.

Keywords: bilateral relations $\cdot$ divide and rule $\cdot$ Nordic cooperation $\cdot$ Russia • small states 